\title{
Fish consumption and risk of breast, colorectal and prostate cancer: a critical evaluation of epidemiological studies
}

\author{
Anette Hjartåker \\ Section of Medical Statistics, Institute for Basic Medical Sciences, University of Oslo, Oslo, Norway
}

\section{Abstract}

The relationship between fish consumption and risk of major cancers such as cancer of the breast, colon, rectum and prostate has been insufficiently clarified. The present literature review of epidemiological studies shows somewhat inconsistent results, but overall there seems to be either no association or an inverse association between fish consumption and risk of breast, colorectal and prostate cancer. However, very few of the published studies have been designed to investigate properly hypotheses regarding fish consumption and cancer risk. Rather, the studies have focused on cancer risk related to meat or fat consumption. Common methodological weaknesses in the studies are combined consumption of lean and fatty fish, or even mixed fish consumption with consumption of chicken, ignoring seasonal variation and different ways of storing, preparing and serving fish, and narrow ranges of exposure. The methodological weaknesses should be borne in mind when evaluating current knowledge on the impact of fish consumption on cancer risk, and when designing new studies.

Keywords: case-control studies; cohort studies; diet; ecological studies; epidemiology; marine foods

Received: 28 Jan. 2003; Revised: 25 Apr. 2003; Accepted: 20 May 2003

\section{Introduction}

Based on various kinds of study, there is broad agreement today that dietary factors may play an important part in carcinogenic processes, as carcinogens, as promoters and as agents that delay the progression of precancerous lesions into neoplastic cells (1). Still, knowledge of how specific dietary factors influence the carcinogenic process is limited.

Regarding marine foods and cancer risk, there have been two main foci: the relationship between the consumption of salted and dried fish and the risk of stomach cancer $(2,3)$ and, more recently, the relationship between the intake of omega-3 fatty acids and the risk of breast, colorectal and prostate cancer (4-6). Two of the major omega-3 fatty acids in fish, eicosapentaenoic acid (EPA, 20:5n-3) and docosahexaenoic acid (DHA, 22:6n-3), seem to decrease the risk of cancer by influencing the activity of enzymes and proteins related to intracellular signalling and cell proliferation (4). Various biological mechanisms have been proposed to explain this finding, including inhibition of eicosanoid biosynthesis from omega-6 precursors (5).
Prostaglandins, unsaturated fatty acids of the eicosanoid family, perform a variety of hormone-like actions and may thus influence cancer initiation and progression. According to a recent discussion (7) eicosanoids may also be involved in processes such as alteration of tumour cell membranes, modulation of oncogene expression and inhibition of mitosis. A significant amount of the research on omega-3 fatty acids and cancer risk has been done on cell lines and animal models. There have been fewer epidemiological studies primarily designed for analyses of fish consumption and cancer risk. In addition to omega3 fatty acids, other constituents of fish, such as fatsoluble vitamins, calcium and selenium, may play a role in the carcinogenic process (8). Also, any favourable effect of fish may be due to replacement of unfavourable foods such as red meat.

The effect that fish, and in particular omega- 3 fatty acid intake, may have on breast cancer, colorectal cancer and prostate cancer risk has been examined before $(7,9)$. This review, as well as giving an extended and updated review of studies on fish consumption and the above-mentioned cancers, will 
discuss methodological weaknesses relevant to many of the published studies.

\section{Overview of epidemiological studies}

\section{Ecological studies}

Studies published in the 1960s and 1970s showed some tendency towards an inverse relationship between per capita consumption of fish and mortality from breast, colorectal and prostate cancer (10-14), but the findings were not strong. Newer population studies have also mainly showed a negative relation between the consumption of fish and fish products and the incidence of or mortality from these cancers.

\section{Breast cancer}

Several studies have, in different ways and with varying strength, reported negative associations between fish consumption and breast cancer mortality (15-20), and between fish consumption and breast cancer incidence (21). However, others have not found any significant association between fish consumption and breast cancer mortality $(22,23)$ or breast cancer incidence $(24,25)$.

\section{Colorectal cancer}

Some of the studies have also reported a negative association between fish consumption and colorectal mortality $(15,19,26)$. No association between fish consumption and colorectal cancer mortality (27-29) and colorectal cancer incidence $(25,30)$ has been seen in other studies. In a Japanese study there was a positive association between fish consumption and colorectal cancer incidence (31).

\section{Prostate cancer}

With respect to prostate cancer and fish consumption, the number of published analyses is fewer. Although the results differ (25), there may be a negative association between fish consumption and this type of cancer as well $(15,24,32)$.

Some of the ecological studies were undertaken within a country or a region, but in most of them data from different countries and even different continents were used. One of the advantages of the ecological studies is thus that the range of fish consumption may be wide (see below). Another advantage is the possibility to investigate fish consumption over a long time and trends in cancer risk. However, the study design suffers from a number of weaknesses, such as the ecological fallacy, i.e. an observed relationship between variables at the population level does not necessary imply that the same relationship will hold at an individual level. Another typical weakness in ecological studies is the lack of ability to achieve appropriate control for potential confounding factors. Ecological studies may be useful to raise hypotheses, but cannot be used for hypothesis testing, which requires analytical studies on an individual level.

\section{Case-control studies}

Breast cancer

Several case-control studies of breast cancer have shown a negative association with fish consumption (33-39), but not all do (40-50). Most of the studies reporting a negative association are undertaken in southern Europe and North America, whereas the studies showing no effect also emerge from the Far East. In a Canadian study cancer patients consumed significantly more fish than controls (51). In some case-control studies no separate analyses of fish consumption were done, but rather of fish combined with white meat. One study in Canada (52) and one in Australia (53) where fish consumption was combined with chicken consumption showed a negative association with breast cancer, whereas two Greek studies where fish consumption was merged with meat and egg consumption showed no association with breast cancer risk $(54,55)$.

\section{Colorectal cancer}

The results regarding fish consumption and colorectal cancer differ. A large number of researchers working in various countries (Belgium, Canada, China, France, Germany, Greece, Italy, Japan, Switzerland and the USA) did not find any obvious association between fish consumption and the risk of colorectal cancer or polyps (56-71). Others have, however, reported a protective effect of fish consumption on colorectal cancer risk $(49,72-79)$, or a protective effect of consumption of shrimps (80). Several of the studies reporting a protective effect were conducted in Italy and Japan, but a protective effect was also reported from studies in Australia, Norway and Argentina. In a study among American Seventh-Day Adventists there was no relationship between colon cancer and current use of fish, whereas use 20 years ago increased the risk of colon 
cancer (81). A couple of studies, one performed in the USA (82) and one in Australia (83), found some weak positive associations between fish consumption and risk of colorectal cancer. Two studies in the USA that analysed fish consumption together with chicken consumption and looked at the ratio of red meat/fish and chicken found a somewhat higher risk of adenomatous polyps among subjects with a high ratio compared with subjects with a lower ratio $(84$, $85)$.

\section{Prostate cancer}

Some studies found that prostate cancer cases report a lower consumption of fish and seafood than men without prostate cancer (86-89), while others found no clear relationship between prostate cancer and fish consumption $(49,90-92)$. All of the studies on prostate cancer were undertaken in North America and Europe, except for one that was conducted in Japan (87). A Swedish study focusing on early life risk factors found that fish consumption during adolescence was positively associated with prostate cancer risk (93), and an American study found an increasing risk with increasing frequency of total meat and fish consumption (94).

Dietary information collected retrospectively, as is the case in most case-control studies, is prone to recall bias. However, low awareness of the specific diet-disease (fish-cancer) research hypothesis in the study population should diminish the risk of such bias.

\section{Cohort studies}

Cohort studies are generally more time- and resource-consuming than ecological and case-control studies, and the number of cohort studies reporting on fish and cancer risk is significantly lower. The study design is, however, stronger, particularly in that the risk of recall bias is minimized as exposure information is typically collected prospectively. The stronger study design implies that stronger emphasis should be placed on the results from cohort studies than on the results from case-control studies, and especially from ecological studies. The published papers based on cohort studies on fish consumption and breast, colon and prostate cancer are therefore described in more detail in Tables 1-3.
Breast cancer

An overview of cohort studies presenting data on breast cancer and fish consumption is given in Table 1. In general, these studies indicate no significant association between fish consumption and breast cancer $(95-100)$.

\section{Colorectal cancer}

Table 2 gives an analogous overview of studies of colorectal cancer. For women, three studies showed no relation between fish consumption and colorectal risk (101-103), and one showed a progressive reduction in risk with increasing consumption of fish and shellfish (104). For men a weak inverse or no relationship was found between colorectal cancer and fish consumption $(101,102,105,106)$. A positive association between the ratio of red meat/ fish and chicken and risk of colorectal cancer was found in one of the studies on women (103) and one of the studies on men (105).

\section{Prostate cancer}

Cohort studies of prostate cancer and fish consumption have in general not shown any relationship (107-112) (Table 3). In a Swedish study men who ate no fish had a two- to three-fold higher frequency of prostate cancer than those who ate moderate or high amounts (113), and in an American study eating fish more than three times a week was associated with a reduced risk of prostate cancer (114). In contrast, a study conducted among Seventh-Day Adventists where the consumption of fish was low showed that increasing fish consumption was associated with an elevated risk of prostate cancer (115).

\section{Methodological weaknesses in the epidemiological studies}

As already pointed out, very few of the published studies have primarily been designed to study the effect that fish may have on cancer risk, and this gives rise to a range of methodological concerns.

\section{Combining lean and fatty fish consumption}

Almost none of the studies separated consumption of different fish species in the analyses. Of all the ecological studies referred to above, none separated lean and fatty fish consumption, although one separated freshwater and saltwater fish consumption (25) and one gave information on fish oil in addition to total fish consumption $(19,26)$. None of 
Table I. Cohort studies reporting on fish consumption and risk of breast cancer

\begin{tabular}{|c|c|c|c|c|}
\hline Publication & $\begin{array}{l}\text { No. of participants/ } \\
\text { no. of cases }\end{array}$ & Comparison & $\begin{array}{l}\text { Relative risk (95\% } \\
\text { confidence limits) }\end{array}$ & Comments \\
\hline Stampfer et al. 1987 (95) & $89538 / 601$ & $\geq 2$ servings of fish week ${ }^{-1}$ vs $\leq 1$ servings month $^{-1}$ & I.I $(0.5-2.4)$ & $\begin{array}{l}\text { From the same data material as } \\
\text { Holmes }(100)\end{array}$ \\
\hline Mills et al. 1989 (96) & $20341 / 115$ & Fish consumption $\geq 1$ time week ${ }^{-1}$ vs never & $1.54(1.00-1.81)$ & Seventh-day Adventists \\
\hline \multirow[t]{2}{*}{ Vatten et al. 1990 (97) } & $14500 / 152$ & $\begin{array}{l}\text { Fish as part of main meal }>2 \text { times week }^{-1} \text { vs } \\
\leq 2 \text { times week }\end{array}$ & $1.2(0.8-1.7)$ & \\
\hline & & $\begin{array}{l}\text { Poached fish as part of main meal } \geq 5 \text { times month } \\
\text { vs }<2 \text { times month }\end{array}$ & $0.7(0.4-1.0)$ & \\
\hline Toniolo et al. 1994 (98) & $14291 / 180$ & Fish intake in grams in 5th quintile vs Ist quintile & $1.02(0.6 I-1.7 I)$ & Nested case-control approach \\
\hline Gertig et al. 1999 (99) & $932 / 466$ & $>0.5$ servings of fish day ${ }^{-1}$ vs $\leq 0.14$ servings day $^{-1}$ & $1.3(0.7-2.6)$ & Nested case-control approach \\
\hline Holmes et al. 2003 (100) & $88647 / 4107$ & $\geq 0.4$ servings of fish day ${ }^{-1}$ vs $\leq 0.13$ servings day ${ }^{-1}$ & $1.04(0.93-1.14)$ & $\begin{array}{l}\text { From the same data material as } \\
\text { Stampfer (95) }\end{array}$ \\
\hline
\end{tabular}

the case-control studies appeared to give results according to the fat content of the fish consumed, except for one study on prostate cancer which gave results on fatty fish consumption only (92). In two Argentine studies on breast and colon cancer the researchers performed separate analyses on seafood (i.e. ocean fish and shellfish) and freshwater fish (43, 76). The picture is the same for the cohort studies, in that only one paper (114) stated that analyses on individual fish dishes ("canned tuna", "fish with dark meat" and "other, unspecified fish dishes") were performed. As shown in Table 4, the nutrient content varies according to the fat content of the fish (116). The proportion of saturated, monounsaturated and polyunsaturated fat varies, and the huge difference in total fat content affects not only the energy content of different fish species, but also the amount of fat-soluble vitamins (A, D, $\alpha$-tocopherol) that may play a role in cancer prevention $(8,117$, 118 ). Fatty fish (defined as containing more than $7 \%$ fat) is particularly important as a source of vitamin D.

Table 2. Cohort studies reporting on fish consumption and risk of colorectal cancer

\begin{tabular}{|c|c|c|c|c|}
\hline Publication & $\begin{array}{l}\text { No. of participants/ } \\
\text { no. of cases }\end{array}$ & Comparison & $\begin{array}{l}\text { Relative risks ( } 95 \% \\
\text { confidence limits) }\end{array}$ & Comments \\
\hline \multicolumn{5}{|l|}{ Women } \\
\hline \multirow[t]{2}{*}{ Willett et al. 1990 (103) } & $88751 / 150$ & $\begin{array}{l}\text { Fish consumption } \geq 5 \text { times } \text { week }^{-1} \\
\text { vs }<1 \text { time month }\end{array}$ & $1.06(0.36-3.12)$ & \\
\hline & & $\begin{array}{l}\text { Ratio of red meat to chicken and fish in } \\
5 \text { th quintile vs Ist quintile }\end{array}$ & $2.49(1.50-4.13)$ & \\
\hline Goldbohm et al. I994 (I0I) & $62573 / 110$ & $>20 \mathrm{~g}$ fish day ${ }^{-1}$ vs $0 \mathrm{~g}$ fish day ${ }^{-1}$ & $0.87(0.52-1.45)$ & Case-cohort approach \\
\hline Gaard et al. 1996 (102) & $24897 / 63$ & 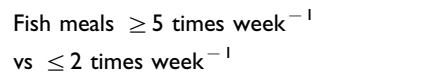 & $0.81(0.30-1.94)$ & \\
\hline \multirow[t]{2}{*}{ Kato et al. 1997 (104) } & $14727 / 100$ & $\begin{array}{l}\text { Fish and shellfish intake in grams in 4th } \\
\text { quartile vs Ist quartile }\end{array}$ & $0.49(0.27-0.89)$ & \\
\hline & & $\begin{array}{l}\text { Ratio of red meat to poultry, fish and } \\
\text { shellfish in 4th quartile vs Ist quartile }\end{array}$ & $1.76(0.93-3.34)$ & \\
\hline \multicolumn{5}{|l|}{ Men } \\
\hline \multirow[t]{2}{*}{ Giovannucci et al. 1994 (105) } & $47949 / 205$ & $\begin{array}{l}\text { Fish intake in grams day }{ }^{-1} \text { in } 5 \text { th quintile } \\
\text { vs Ist quintile }\end{array}$ & $1.06(0.70-1.60)$ & From the same material as $\mathrm{Ma}(\mathrm{I06})$ \\
\hline & & $\begin{array}{l}\text { Ratio of red meat to chicken and fish in } \\
5 \text { th quintile vs Ist quintile }\end{array}$ & $1.83(1.17-2.85)$ & \\
\hline Goldbohm et al. I994 (I0I) & $58279 / 105$ & $>20 \mathrm{~g}_{\text {fish day }}{ }^{-1}$ vs $0 \mathrm{~g}$ fish day ${ }^{-1}$ & $0.73(0.44-1.21)$ & Case-cohort approach \\
\hline Gaard et al. 1996 (102) & $25638 / 87$ & $\begin{array}{l}\text { Fish meals } \geq 5 \text { times week }^{-1} \\
\text { vs } \leq 2 \text { times week }^{-1}\end{array}$ & $0.46(0.19-1.11)$ & \\
\hline Ma et al. 2001 (106) & $14916 / 193$ & $\begin{array}{l}\text { Servings of fish day }{ }^{-1} \text { in } 3 r d \text { tertile } \\
\text { vs Ist tertile }\end{array}$ & $0.92(0.56-1.51)$ & $\begin{array}{l}\text { From the same material as Giovannucci (105). } \\
\text { Nested case-control approach }\end{array}$ \\
\hline
\end{tabular}


Table 3. Cohort studies reporting on fish consumption and risk of prostate cancer

\begin{tabular}{|c|c|c|c|c|}
\hline Publication & $\begin{array}{l}\text { No. of participants/ } \\
\text { no. of cases }\end{array}$ & Comparison & $\begin{array}{l}\text { Relative risks }(95 \% \\
\text { confidence limits) }\end{array}$ & Comments \\
\hline Hirayama 1979 (107) & $122261 / 63$ & Fish intake daily vs occasionally/rarely/none & 5.7 vs 5.8 & Death rate \\
\hline Severson et al. 1989 (108) & $7999 / 174$ & $\begin{array}{l}\text { Fish consumption } \geq 5 \text { times week }{ }^{-1} \text { vs } \\
\leq 1 \text { time week }\end{array}$ & $1.22(0.74-2.01)$ & \\
\hline Mills et al. 1989 (115) & ca $14000 / 180$ & Fish consumption $\geq 1$ time week ${ }^{-1}$ vs never & $1.57(0.88-2.78)$ & Seventh-Day Adventists \\
\hline Hsing et al. 1990 (109) & $17633 / 149$ & $\begin{array}{l}\text { Fish consumption }>4.0 \text { times month }{ }^{-1} \text { vs } \\
<0.8 \text { times month }^{-1}\end{array}$ & $0.8(0.5-1.3)$ & \\
\hline Le Marchand et al. 1994 (II0) & $20316 / 198$ & Fish intake in grams in 4th quartile vs Ist quartile & $1.22(0.8-1.8)$ & \\
\hline Veierød et al. 1997 (III) & $25708 / 72$ & Main meals with fish & No association & Risk estimates not shown \\
\hline Schuurman et al. 1999 (I I2) & $58279 / 642$ & $20 \mathrm{~g}_{\text {fish day }}{ }^{-1}$ vs $0 \mathrm{~g}$ fish day $^{-1}$ & $1.03(0.80-1.34)$ & \\
\hline Terry et al. 2001 (1 13) & $6272 / 466$ & $\begin{array}{l}\text { Fish consumption as moderate part of diet vs } \\
\text { seldom/never fish consumption }\end{array}$ & $0.4(0.2-0.8)$ & \\
\hline Augustsson et al. 2003 (II4) & $47882 / 2482$ & Fish consumption $>3$ times week $^{-1}$ vs $<2$ times month $^{-1}$ & $\begin{array}{l}0.93(0.80-1.08) \\
0.56(0.37-0.86)\end{array}$ & $\begin{array}{l}\text { All prostate cancer } \\
\text { Metastatic prostate cancer }\end{array}$ \\
\hline
\end{tabular}

Table 4. Content of potentially cancer-relevant nutrients in lean and fatty fish (typical range of nutrient content per $100 \mathrm{~g}$ edible food)

\begin{tabular}{lll}
\hline Nutrient & Lean fish & Fatty fish \\
\hline Energy $(\mathrm{kJ})$ & $250-520$ & $660-1500$ \\
Protein $(\mathrm{g})$ & $15-20$ & $12-20$ \\
Fat $(\mathrm{g})$ & $0.1-6$ & $7-30$ \\
Saturated fat $(\mathrm{g})$ & $0.02-0.5$ & $2-5$ \\
$(\%)$ & $14-20$ & $11-25$ \\
Monounsaturated fat $(\mathrm{g})$ & $0.02-1.2$ & $3-10$ \\
$(\%)$ & $10-35$ & $36-58$ \\
Polyunsaturated fat $(\mathrm{g})$ & $0.04-1.0$ & $1-6$ \\
$(\%)$ & $30-45$ & $7-24$ \\
Cholesterol $(\mathrm{mg})$ & $25-80$ & $40-70$ \\
Retinol $(\mu \mathrm{g})$ & $0-80$ & $0-60$ \\
Vitamin D $(\mu \mathrm{g})$ & $0-7$ & $7-30$ \\
$\alpha$-tocopherol $(\mathrm{mg})$ & $0.2-1.7$ & $0.6-2.7$ \\
Iron $(\mathrm{mg})$ & $0.1-0.6$ & $0.1-1.0$ \\
Calcium $(\mathrm{mg})$ & $8-80$ & $6-47$ \\
Selenium $(\mu \mathrm{g})$ & $20-50$ & $20-50$ \\
\hline & &
\end{tabular}

Source: Ref. (116).

The varying nutrient content of different fish should indicate that separate analysis of individual species or of fish subgroups, such as lean and fatty fish, could be important when examining fish consumption in relation to cancer. Although not presented in the publications, consumption data on different fish species were collected in many of the studies, according to their method section. The reasons for not utilizing this information may be that fish was not the main focus of the study, or that the total fish consumption was too low to perform meaningful subgroup analyses.

\section{Combining fish and chicken consumption}

Going one step further, by not only combining different kinds of fish but also merging fish consumption with chicken consumption, leads to even more difficulties. Several of the studies referred to in the present overview made use of such a white meat (fish plus chicken) index in their analysis (e.g. $(38,52,53,58,67,84,85,96,100,103,115))$. Chicken contains a higher proportion of saturated and monounsaturated fat than fish, and correspondingly a lower proportion of polyunsaturated fat. The differences are particularly marked with respect to the omega-3 essential fatty acids EPA and DHA. In fish, EPA constitutes $5-15 \%$ of the fatty acids and DHA constitutes some 7-38\%. The corresponding figures for chicken are 0.3 and $0.6 \%$, respectively (119). The content of cholesterol is about twice as high in chicken as in fish (116). So far, the scientific evidence suggests that there is probably no association between dietary cholesterol and risk of breast cancer, whereas any association between dietary intake of cholesterol and risk of colorectal and prostate cancer has been insufficiently examined (8). Both fish and chicken are good sources of protein. In lean fish species $(0-3 \%$ fat) protein constitutes more than $90 \%$ of the energy content. The protein is easily digestible and has a favourable amino acid composition. The amino acid pattern varies from species to species (120). Chicken contains about twice the amount of proline and glycine compared to fish, and has a somewhat higher content of isoleucine and arginine (120). No association between intake of individual amino acids or total protein intake and cancer has been 
established, although a positive association between total animal protein intake and cancer has been hypothesized (8). As already stated, the content of fat-soluble vitamins varies among fish species, but in total fish contains more vitamin A, vitamin D and $\alpha$-tocopherol than chicken (116). Smoked mackerel and salted and pickled herring contain about the same amount of iron as chicken, whereas fish in general has a low iron content (116). It has been suggested that iron may increase the risk of colorectal cancer, but as yet, the evidence is insufficient (8). The content of calcium is considerably higher in fish than in poultry (116). The calcium content of fish varies greatly between different fish species, and is dependent on the amount of bone in the ready-to-eat fish. The effect of calcium on cancer risk is uncertain, but it may have a beneficial effect on risk of colorectal cancer and an adverse effect on prostate cancer risk (117). Fish contains more selenium than many other food items (116) and contributes significantly to the intake of this trace element, which has been proposed to have anticarcinogenic effects (121). Although most of the studies that combine fish consumption with chicken consumption also provide separate data on fish consumption, not all of them do $(84,85)$.

\section{The red meat/white meat ratio}

In contrast to the low interest that has been shown to fish and fish products, a large number of studies have focused on the relationship between red meat consumption and cancer risk (e.g. $(122,123))$, and the studies referred to in the present paper give data on meat consumption in addition to data on fish. The relationship between different food items and cancer is sometimes difficult to interpret because of intercorrelation between the items $(12,52,124$, 125). Reported intake of red meat may be negatively correlated with reported intake of white meat (103). It has been recommended that red meat should be replaced by white meat, and the red meat/white meat ratio has been used as an indicator of compliance with this recommendation. Several studies on breast and colorectal cancer $(39,82,84$, $85,104)$, including the Nurses Health Study (103) and the Health Professionals Follow-up Study (105), place great emphasis on this ratio, and thus focus not on the consumption of fish per se, but rather on the consumption of white meat in relation to red meat.
Quantity of fish consumption: frequencies and amount consumed

Most studies do not provide data on actual frequencies of fish consumption or on the amounts consumed. Again, this may be due to the lack of interest shown in fish as a risk factor for cancer. The prospective studies that do provide data on frequencies and amounts demonstrate a rather low consumption in many populations. For instance, in an American study the following frequencies of fish consumption were applied in the analyses: less than 0.8 times month ${ }^{-1}, 0.8-1.7$ times month ${ }^{-1}, 1.8-$ 4.0 times month ${ }^{-1}$ and more than 4.0 times month $^{-1}$ (109). This includes all kind of fish dishes. In comparison, the meat categories ranged from 17 to 39 times per month. European studies have also applied categories that indicate low consumption of fish: do not eat fish, $0-10 \mathrm{~g} \mathrm{day}^{-1}, 10-20 \mathrm{~g} \mathrm{day}^{-1}$ or more than $20 \mathrm{~g} \mathrm{day}^{-1}$ (101). In an ecological study in China the median frequency of fish

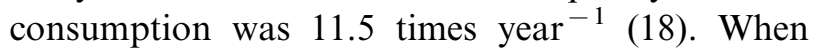
discussing the association between fat intake and cancer risk it is argued that conflicting results may to some extent be explained by too narrow a range of exposure $(54,123,126-129)$. This argument may also be relevant when investigating the relationship between fish and breast, colorectal and prostate cancer risk.

\section{Preservation and preparation}

Studies on breast, colorectal and prostate cancer and fish hardly ever give any information on whether and how the fish has been preserved and how it is prepared. Typically, only one or a few categories are used for estimating fish consumption, and fresh, frozen, dried, salted and hermetically preserved fish are thereby considered together. Still, in several studies some information about preservation methods was collected (e.g. $(36,39,41,48,57$, $61,66,110)$ ), although only 10 studies took this information into account in the analysis $(40,43,56$, $60,67,76,86,89,102,114)$. Furthermore, although there are exceptions $(38,60,97,102)$, there is typically no distinction between consumption of steamed, boiled, fried and grilled fish, and fish fillet and fish dishes (containing ingredients such as flour, milk, etc.) are treated together. In a Norwegian cohort study where preparation method was taken into account, consumption of poached fish showed a negative association with breast cancer, whereas total fish consumption did not (97). In parallel to 
information on different fish species and preservation (see above), some studies collected information on preparation but did not use this in the analyses (e.g. $(36,37))$. Although no information on preservation and preparation was given in the majority of the publications, it cannot be ruled out that such information was collected. The same goes for information on accompaniments and seasonal variation (see below).

\section{Accompaniments}

The studies do not provide data on the accompaniments served with fish. In Norway, for instance, there is a long tradition of serving melted fat, solid fat and various milk-based sauces with fish. With some fish dishes fish juice, sour cream or mayonnaise-based dressings are served, and with other fish dishes roe, fish liver and fried bacon. Only one of all the studies referred to in this overview clearly stated that information on accompaniments to fish had been collected and applied in the analyses (102). In that study fat consumed with fish meals was analysed together with all other edible fat. Information on how the fish is prepared and what accompanying dishes come with it is particularly important for high-consumption populations.

\section{Seasonal variation}

Today's fish supply is less dependent on seasonal variation than it was some decades ago. Still, there is reason to believe that the fish consumption pattern varies through the year. Some species, e.g. herring and mackerel, can only be harvested during limited periods of the year. In addition to the shifting fish supply, the nutrient content of some fish species varies according to the harvesting season. The author knows of only two case-control studies from Argentina that clearly report on taking seasonal variation into account when collecting data on fish consumption $(43,76)$.

\section{Discussion}

The relationship between fish consumption and risk of breast, colorectal and prostate cancer has been insufficiently elucidated. Overall, there seems to be either no association or possibly a reduced risk with higher consumption of fish. This conclusion has also been reached by others $(7,9)$. In particular, a negative association between fish consumption and breast, colorectal and prostate cancer risk was reported from ecological studies, but a negative association was also found in a number of casecontrol studies. The results from cohort studies are less optimistic, although the latest cohort study on prostate cancer is encouraging (114). In addition to the different basic design of the studies, the studies varies with regard to sample size, adjustment for potential confounding factors, detail and quality of the dietary assessment methods and amount of fish consumed. These differences may contribute to the discrepancies in the literature, although no clear pattern appears.

The constituents of fish that have been given by far the most attention are the omega-3 fatty acids EPA and DHA. Research on cancer cell lines and animal models has shown that these fatty acids can reduce cell proliferation and tumour progression (4, $5,7)$. These results need to be confirmed in human studies.

To date, very few epidemiological studies have been designed to investigate properly hypotheses regarding fish consumption and cancer risk, whether concentrating on omega-3 fatty acids or on other constituents of fish, such as fat-soluble vitamins, calcium or selenium. Current results have often emerged as by-products from studies focusing on other food items or on larger food groups (e.g. animal foods). As fish is not the main issue in the studies, there is a chance that some no-effect results are not reported. Fish is usually treated as a homogeneous food item, even though the nutrient content varies significantly between different species. The problem of collapsing food items with dissimilar nutrient content becomes even greater when fish consumption is merged with consumption of other white meat. Different ways of storing, preparing and serving fish are not taken into account, nor is seasonal variation. These aspects should be considered in future studies. Future studies should also aim at capturing a wide range of exposure, and as cancer develops over time information on long-term consumption would be valuable. To distinguish between the effect of omega-3 fatty acids and fish per se, information on consumption of fish oil capsules and cod liver oil should be collected if relevant for the actual population.

Carefully designed case-control studies could provide useful information on the relationship between fish consumption and cancer, although cohort studies undertaken in different populations are preferable. The European Prospective Investiga- 
tion into Cancer and Nutrition (EPIC) is a large $(n>500000)$, ongoing, multicentre cohort study that hopefully will provide better understanding of the relationship between fish consumption and cancer risk. In addition to dietary data, blood samples that can be used as biomarkers of diet have been collected (130). Based on very detailed information from $24 \mathrm{~h}$ dietary recalls from a subsample of the cohort $(n \sim 36000)$ it was concluded that, throughout Europe, substantial geographical variation exists in total and subgroup fish intake and in the number of fish types consumed (131). This provides a good basis for the investigation of fish consumption and cancer risk. The Norwegian Women and Cancer Study (NOWAC), one out of 10 subcohorts included in EPIC, is to the author's knowledge presently the only cohort study especially designed to look into fish consumption and cancer risk (132). In NOWAC, consumption of a number different fish species and fish dishes is collected separately, as well as information on seasonal variation, accompaniments, preparation methods, and consumption of fish oil capsules and cod liver oil (133).

As this review shows, there is a large potential for methodological improvements in epidemiological studies on fish consumption and cancer. Taking the aspects discussed above into account when designing and analysing studies should improve the research on the relationship between this important food group and major chronic diseases.

\section{References}

1. Hursting SD, Fischer SM, Wargovich MJ, Digiovanni J. Nutritional modulation of the carcinogenic process. In: Heber D, Blackburn GL, Go VLW, eds. Nutritional oncology. San Diego, CA: Academic Press; 1999. p. 91-104.

2. Boeing H. Epidemiological research in stomach cancer: progress over the last ten years. J Cancer Res Clin Oncol 1991; 117: 133-43.

3. IARC. Salted fish. IARC monographs on the evaluation of carcinogenic risks to humans. 1993;56:41-82.

4. Bartsch H, Nair J, Owen RW. Dietary polyunsaturated fatty acids and cancers of the breast and colorectum: emerging evidence for their role as risk modifiers. Carcinogenesis 1999; 20: 2209-18.

5. Rose DP, Connolly JM. Omega-3 fatty acids as cancer chemopreventive agents. Pharmac Ther 1999; 83: $217-$ 44.

6. Zhou J-R, Blackburn GL. Dietary lipid modulation of immune response in tumorigenesis. In: Heber D,
Blackburn GL, Go VLW, eds. Nutritional oncology. San Diego, CA: Academic Press; 1999. p. 195-213.

7. Terry PD, Rohan TE, Wolk A. Intakes of fish and marine fatty acids and the risk of cancers of the breast and prostate and of other hormone-related cancers: a review of the epidemiologic evidence. Am J Clin Nutr 2003; 77: 532-43.

8. World Cancer Research Found and American Institute for Cancer Research. Food, nutrition and the prevention of cancer: a global perspective. Washington, DC: American Institute for Cancer Research; 1997.

9. de Deckere EAM. Possible beneficial effect of fish and fish n-3 polyunsaturated fatty acids in breast and colorectal cancer. Eur J Cancer Prev 1999; 8: 213-21.

10. Lea AJ. Neoplasms and environmental factors. Ann R Coll Surg Engl 1967; 41: 432-8.

11. Howell MA. Factor analysis of international cancer mortality data and per capita food consumption. Br J Cancer 1974; 29: 328-36.

12. Schrauzer GN. Cancer mortality correlation studies. II. Regional associations of mortalities with the consumptions of foods and other commodities. Med Hypotheses 1976; 2: 39-49.

13. Maruchi N, Aoki S, Tsuda K, Tanaka Y, Toyokawa H. Relation of food consumption to cancer mortality in Japan, with special reference to international figures. Gann 1977; 68: 1-13.

14. Hirayama T. Epidemiology of breast cancer with special reference to the role of diet. Prev Med 1978; 7: $173-95$.

15. Decarli A, La Vecchia C. Environmental factors and cancer mortality in Italy: correlation exercise. Oncology 1986; 43: 116-26.

16. Taioli E, Nicolosi A, Wynder EL. Dietary habits and breast cancer: a comparative study of United States and Italian data. Nutr Cancer 1991; 16: 259-65.

17. Zang EA, Barrett NO, Cohen LA. Differences in nutritional risk factors for breast cancer among New York City white, Hispanic, and black college students. Ethnicity Dis 1994; 4: 28-40.

18. Guo WD, Chow WH, Zheng W, Li JY, Blot WJ. Diet, serum markers and breast cancer mortality in China. Jpn J Cancer Res 1994; 85: 572-7.

19. Caygill CPJ, Charlett A, Hill MJ. Fat, fish, fish oil and cancer. Br J Cancer 1996; 74: 159-64.

20. Hebert JR, Rosen A. Nutritional, socioeconomic, and reproductive factors in relation to female breast cancer mortality: findings from a cross-national study. Cancer Detect Prev 1996; 20: 234-44.

21. Kaizer L, Boyd NF, Kriukov V, Tritchler D. Fish consumption and breast cancer risk: an ecological study. Nutr Cancer 1989; 12: 61-8.

22. Gaskill SP, McGuire WL, Osborne CK, Stern MP. Breast cancer mortality and diet in the United States. Cancer Res 1979; 39: 3628-37.

23. Ishimoto H, Nakamura H, Miyoshi T. Epidemiological study on relationship between breast cancer mortality and dietary factors. Tokushima J Exp Med 1994; 41: $103-14$. 
24. Kolonel JN, Nomura AMY, Hinds MW, Hirohata T, Hankin JH, Lee J. Role of diet in cancer incidence in Hawaii. Cancer Res 1983; 43(Suppl): 2397-2402S.

25. Koo LC, Mang OWK, Ho JH-C. An ecological study of trends in cancer incidence and dietary changes in Hong Kong. Nutr Cancer 1997; 28: 289-301.

26. Caygill CPJ, Hill MJ. Fish, n-3 fatty acids and human colorectal and breast cancer mortality. Eur J Cancer Prev 1995; 4: 329-32.

27. McKeown-Eyssen GE, Bright-See E. Dietary factors in colon cancer: international relationships. Nutr Cancer 1984; 6: 160-70.

28. Kato I, Tominaga S, Kuroishi T. Per capita foods/ nutrients intake and mortality from gastrointestinal cancers in Japan. Jpn J Cancer Res 1987; 78: 453-9.

29. Zhuo X-G, Watanabe S. Factor analysis of digestive cancer mortality and food consumption in 65 Chinese counties. J Epidemiol 1999; 9: 275-84.

30. Jensen OM, MacLennan R, Wahrendorf J. Diet, bowel function, fecal characteristics, and large bowel cancer in Denmark and Finland. Nutr Cancer 1982; 4: 5-19.

31. Hara N, Sakata K, Nagai M, Fujita Y, Hashimoto T, Yanagawa H. Statistical analyses of the pattern of food consumption and digestive-tract cancers in Japan. Nutr Cancer 1985; 6: 220-8.

32. Hebert JR, Hurley TG, Olendzki BC, Teas J, Ma Y, Hampl JS. Nutritional and socioeconomic factors in relation to prostate cancer mortality: a cross-national study. J Natl Cancer Inst 1998; 90: 1637-47.

33. Hislop GT, Coldman AJ, Elwood JM, Brauer G, Kan L. Childhood and recent eating patterns and risk of breast cancer. Cancer Detect Prev 1986; 9: 47-58.

34. Malik IA, Sharif S, Malik F, Hakimali A, Khan WA, Badruddin SH. Nutritional aspects of mammary carcinogenesis: a case-control study. J Pak Med Assoc 1993; 43: 118-20.

35. Landa MC, Frago N, Tres A. Diet and the risk of breast cancer in Spain. Eur J Cancer Prev 1994; 3: $313-$ 20.

36. Franceschi S, Favero A, La Vecchia C, Negri E, Dal Maso L, Salvini S, et al. Influence of food groups and food diversity on breast cancer risk in Italy. Int $\mathbf{J}$ Cancer 1995; 63: 785-9.

37. Hirose $\mathrm{K}$, Tajima $\mathrm{K}$, Hamajima $\mathrm{N}$, Inoue $\mathrm{M}$, Takezaki T, Kuroishi T, et al. A large-scale, hospital-based casecontrol study of risk factors of breast cancer according to menopausal status. Jpn J Cancer Res 1995; 86: 14654.

38. De Stefani E, Ronco A, Mendilaharsu M, Guidobono M, Deneo-Pellegrini H. Meat intake. Heterocyclic amines, and risk of breast cancer: a case-control study in Uruguay. Cancer Epidemiol Biomarkers Prev 1997; 6: $573-81$

39. Ambrosone CB, Freudenheim JL, Sinha R, Graham S, Marshall JR, Vena JE, et al. Breast cancer risk, meat consumption and n-acetyltransferase (NAT2) genetic polymorphisms. Int J Cancer 1998; 75: 825-30.

40. Hirohata T, Shigematsu T, Nomura AMY, Nomura Y, Horie A, Hirohata I. Occurrence of breast cancer in relation to diet and reproductive history: a case-control study in Fukuoka, Japan. Natl Cancer Inst Monogr 1985; 69: 187-90.

41. Hirohata T, Nomura AMY, Hankin JH, Kolonel LN, Lee J. An epidemiologic study on the association between diet and breast cancer. J Natl Cancer Inst 1987; 78: 595-600.

42. La Vecchia C, Decarli A, Franceschi S, Gentile A, Negri E, Parazzini F. Dietary factors and the risk of breast cancer. Nutr Cancer 1987; 10: 205-14.

43. Iscovich JM, Iscovich RB, Howe G, Shiboski S, Kaldor JM. A case-control study of diet and breast cancer in Argentina. Int J Cancer 1989; 44: 770-6.

44. Toniolo P, Riboli E, Protta F, Charrel M, Cappa APM. Calorie-providing nutrients and risk of breast cancer. J Natl Cancer Inst 1989; 81: 278-86.

45. Lee HP, Gourley L, Duffy SW, Estève J, Lee J, Day NE. Dietary effects on breast-cancer risk in Singapore. Lancet 1991; 337: 1197-200.

46. Richardson S, Gerber M, Cenée S. The role of fat, animal protein and some vitamin consumption in breast cancer: a case-control study in Southern France. Int J Cancer 1991; 48: 1-9.

47. Kato I, Miura S, Kasumi F, Iwase T, Tashiro H, Fujita Y, et al. A case-control study of breast cancer among Japanese women: with special reference to family history and reproductive and dietary factors. Breast Cancer Res Treat 1992; 24: 51-95.

48. Yuan J-M, Wang Q-S, Ross RK, Henderson BE, Yu MC. Diet and breast cancer in Shanghai and Tianjin, China. Br J Cancer 1995; 71: 1353-8.

49. Fernandez E, Chatenoud L, La Vecchia C, Negri E, Franceschi S. Fish consumption and cancer risk. Am J Clin Nutr 1999; 70: 85-90.

50. Männistö S, Pietinen $\mathrm{P}$, Virtanen $\mathrm{M}$, Kataja V, Uusitupa M. Diet and the risk of breast cancer in a case-control study: does the threat of disease have an influence on recall bias? J Clin Epidemiol 1999; 5: 42939.

51. Simard A, Vobecky J, Vobecky JS. Nutrition and lifestyle factors in fibrocystic disease and cancer of the breast. Cancer Detect Prev 1990; 14: 567-72.

52. Lubin JH, Burns PE, Blot WJ, Ziegler RG, Lees AW, Fraumen JF Jr. Dietary factors and breast cancer risk. Int J Cancer 1981; 28: 685-9.

53. Ingram DM, Nottage $\mathrm{E}$, Roberts $\mathrm{T}$. The role of diet in the development of breast cancer: a case-control study of patients with breast cancer, benign epithelial hyperplasia and fibrocystic disease of the breast. Br J Cancer 1991; 64: 187-91.

54. Katsouyanni K, Trichopoulos D, Boyle P, Xirouchaki E, Trichopoulou A, Lisseos B, et al. Diet and breast cancer: a case-control study in Greece. Int $\mathbf{J}$ Cancer 1986; 38: 815-20.

55. Trichopoulou A, Katsouyanni K, Stuver S, Tzala L, Gnardellis C, Rimm E, et al. Consumption of olive oil and specific food groups in relation to breast cancer risk in Greece. J Natl Cancer Inst 1995; 87: 110-6.

56. Haenszel W, Berg JW, Segi M, Kurihara M, Locke FB. Large-bowel cancer in Hawaiian Japanese. J Natl Cancer Inst 1973; 51: 1765-79. 
57. Dales LG, Friedman GD, Ury HK, Grossman S, Williams SR. A case-control study of relationships of diet and the other traits to colorectal cancer in American blacks. Am J Epidemiol 1978; 109: 132-44.

58. Manousos O, Day NE, Trichopoulos D, Gerovassilis F, Tzonou A, Polychronopoulou A. Diet and colorectal cancer: a case-control study in Greece. Int $\mathbf{J}$ Cancer 1983; 32: 1-5.

59. Miller AB, Howe GR, Jain M, Craib KJP, Harrison L. Food items and food groups as risk factors in a casecontrol study of diet and colo-rectal cancer. Int $\mathbf{J}$ Cancer 1983; 32: 155-61.

60. Tajima K, Tominaga S. Dietary habits and gastrointestinal cancers: a comparative case-control study of stomach and large intestinal cancers in Nagoya, Japan. Jpn J Cancer Res 1985; 76: 705-16.

61. Macquart-Moulin G, Riboli E, Cornée J, Charnay B, Berthezène $\mathrm{P}$, Day N. Case-control study on colorectal cancer and diet in Marseilles. Int J Cancer 1986; 38: $183-91$.

62. Tuyns AJ, Kaaks R, Haelterman M. Colorectal cancer and the consumption of foods: a case-control study in Belgium. Nutr Cancer 1988; 11: 189-204.

63. Lee HP, Gourley L, Duffy SW, Estève J, Lee J, Day NE. Colorectal cancer and diet in an Asian population - a case-control study among Singapore Chinese. Int $\mathbf{J}$ Cancer 1989; 43: 1007-16.

64. Benito E, Obrador A, Stiggelbout A, Bosch FX, Munoz N, Kaldor J. A population-based case-control study of colorectal cancer in Majorca. I. Dietary factors. Int J Cancer 1990; 45: 69-76.

65. Bidoli E, Franceschi S, Talamini R, Barra S, La Vecchia C. Food consumption and cancer of the colon and rectum in north-eastern Italy. Int J Cancer 1992; 50: 223-9.

66. Peters RK, Pike M, Garabrant D, Mack TM. Diet and colon cancer in Los Angeles County, California. Cancer Causes Control 1992; 3: 457-73.

67. Centonze S, Boeing H, Leoci C, Guerra V, Misciagna G. Dietary habits and colorectal cancer in a low-risk area. Results from a population-based case-control study in southern Italy. Nutr Cancer 1994; 21: 233-46.

68. Kampman E, Verhoeven D, Sloots L, van't Veer P. Vegetable and animal products as determinants of colon cancer risk in Dutch men and women. Cancer Causes Control 1995; 6: 225-34.

69. Le Marchand L, Wilkens LR, Hankin JH, Kolonel LN, Lyu L-C. A case-control study of diet and colorectal cancer in a multiethnic population in Hawaii (United States): lipids and foods of animal origin. Cancer Causes Control 1997; 8: 637-48.

70. Boutron-Ruault M-C, Senesse P, Faivre J, Chatelain N, Belghiti C, Méance S. Foods as risk factors for colorectal cancer: a case-control study in Burgundy (France). Eur J Cancer Prev 1999; 8: 229-35.

71. Levi F, Pasche C, La Vecchia C, Lucchini F, Franceschi S. Food groups and colorectal risk. Br J Cancer 1999; 79: 1283-7.

72. Bjelke E. Epidemiologic studies of cancer of the stomach, colon and rectum. Vol III. Case-control study of gastrointestinal cancer in Norway. Ann Arbor, MI: University Microfilms; 1973.

73. Kune S, Kune GA, Watson LF. Case-control study of dietary etiological factors: the Melbourne colorectal cancer study. Nutr Cancer 1987; 9: 21-42.

74. La Vecchia C, Negri E, Decarli A, D’Avanco B, Gallotti L, Gentile A, et al. A case-control study of diet and colo-rectal cancer in northern Italy. Int $\mathbf{J}$ Cancer 1988; 41: 492-8.

75. Kato I, Tominaga S, Matsuura A, Yoshii Y, Shirai M, Kobayashi S. A comparative case-control study of colorectal cancer and adenoma. Jpn J Cancer Res 1990; 81: 1101-8.

76. Iscovich JM, L'abbé KA, Castelleto R, Calzona A, Bernedo A, Chopita NA, et al. Colon cancer in Argentina. I: Risk from intake of dietary items. Int $\mathbf{J}$ Cancer 1992; 51: 851-7.

77. Kotake K, Koyama Y, Nasu J, Fukutomi T, Yamaguchi $\mathrm{N}$. Relation of family history of cancer and environmental factors to the risk of colorectal cancer: a casecontrol study. Jpn J Clin Oncol 1995; 25: 195-202.

78. Franceschi S, Favero A, La Vecchia C, Negri E, Conti E, Montella M, et al. Food groups and risk of colorectal cancer in Italy. Int J Cancer 1997; 72: 56-61.

79. Franceschi S, Favero A, Parpinel M, Giacosa A, La Vecchia C. Italian study on colorectal cancer with emphasis on influence of cereals. Nutr Cancer 1998; 7(Suppl 2): S19-23.

80. Haenszel W, Locke FB, Segi M. A case-control study of large bowel cancer in Japan. J Natl Cancer Inst 1980; 64: $17-22$.

81. Phillips RL. Role of life-style and dietary habits in risk of cancer among Seventh-Day Adventists. Cancer Res 1975; 35: 3513-22.

82. Graham S, Dayal H, Swanson M, Mittelman A, Wilkinson G. Diet in the epidemiology of cancer of the colon and rectum. J Natl Cancer Inst 1978; 61: 709-14.

83. Steinmetz KA, Potter JD. Food-group consumption and colon cancer in the Adelaide case-control study. II. Meat, poultry, seafood, dairy foods and eggs. Int $\mathbf{J}$ Cancer 1993; 53: 720-7.

84. Neugut AI, Garowski GC, Lee WC, Murray T, Nieves JW, Forde KA, et al. Dietary risk factors for the incidence and recurrence of colorectal adenomatous polyps: a case-control study. Ann Intern Med 1993; 118: $91-5$.

85. Sandler RS, Lyles CM, Peipins LA, McAuliffe CA, Woosley JT, Kupper LL. Diet and risk of colorectal adenomas: macronutrients, cholesterol, and fiber. $\mathbf{J}$ Natl Cancer Inst 1993; 85: 884-91.

86. Schuman LM, Mandel JS, Radke A, Seal U, Halberg F. Some selected features of the epidemiology of prostatic cancer: Minneapolis-St. Paul, Minnesota case-control study, 1976-1979. In: Magnus K, ed. Trends in cancer incidence. Causes and practical implications. New York: Hemisphere; 1982. p. 345-54.

87. Mishina T, Watanabe H, Araki H, Nakao M. Epidemiological study of prostatic cancer by matched-pair analysis. Prostate 1985; 6: 423-36. 
88. Ewings P, Bowie C. A case-control study of cancer of the prostate in Somerset and east Devon. Br J Cancer 1996; 74: 661-6.

89. Pawlega J, Rachtan J, Dyba T. Dietary factors and risk of prostate cancer in Poland. Results of case-control study. Neoplasma 1996; 43: 61-3.

90. Talamini R, Franceschi S, La Vecchia C, Serraino D, Barra S, Negri E. Diet and prostatic cancer: a casecontrol study in Northern Italy. Nutr Cancer 1992; 18: 277-86.

91. Whittemore AS, Kolonel LN, Wu AH, John EM, Gallagher RP, Howe GR, et al. Prostate cancer in relation to diet, physical activity, and body size in Blacks, Whites, and Asians in the United States and Canada. J Natl Cancer Inst 1995; 87: 652-61.

92. Key TJA, Silcocks PB, Davey GK, Appleby PN, Bishop DT. A case-control study of diet and prostate cancer. Br J Cancer 1997; 76: 678-87.

93. Andersson S-O, Baron J, Wolk A, Lindgren C, Bergström R, Adami H-O. Early life risk factors for prostate cancer: a population-based case-control study in Sweden. Cancer Epidemiol Biomark Prev 1995; 4: 187-92.

94. Graham S, Haughey B, Marshall J, Priore R, Byers T, Rzepka $\mathrm{T}$, et al. Diet in epidemiology of carcinoma of the prostate gland. J Natl Cancer Inst 1983; 70: 68792.

95. Stampfer MJ, Willett WC, Colditz GA, Speizer FE. Intake of cholesterol, fish and specific types of fat in relation to risk of breast cancer. In: Lands WEM, ed. Proceedings of the AOCS short course on polyunsaturated fatty acids and eicosanoids. Champaign, IL: AOCS; 1987.

96. Mills PK, Beeson WL, Phillips RL, Fraser GE. Dietary habits and breast cancer incidence among Seventh-day Adventists. Cancer 1989; 64: 582-90.

97. Vatten LJ, Solvoll K, Løken EB. Frequency of meat and fish intake and risk of breast cancer in a prospective study of 14500 Norwegian women. Int J Cancer 1990; 46: 12-5.

98. Toniolo P, Riboli E, Shore RE, Pasternack BS. Consumption of meat, animal products, protein and fat and risk of breast cancer: a prospective cohort study in New York. Epidemiology 1994; 5: 391-7.

99. Gertig DM, Hankinson SE, Hough H, Spiegelman D, Colditz G, Willett WC, et al. N-acetyl transferase 2 genotypes, meat intake and breast cancer risk. Int $\mathrm{J}$ Cancer 1999; 80: 13-7.

100. Holmes MD, Colditz GA, Hunter DJ, Hankinson SE, Rosner B, Speizer FE, et al. Meat, fish and egg intake and risk of breast cancer. Int J Cancer 2003; 104: 221 7.

101. Goldbohm RA, van den Brandt PA, van't Veer P, Brants HAM, Dorant E, Sturmans F, et al. A prospective cohort study on the relation between meat consumption and risk of colon cancer. Cancer Res 1994; 54: 718-23.

102. Gaard M, Tretli S, Løken EB. Dietary factors and risk of colon cancer: a prospective study of 50, 535 young
Norwegian men and women. Eur J Cancer Prev 1996; 5: $445-54$

103. Willett WC, Stampfer MJ, Colditz GA, Rosner BA, Speizer FE. Relation of meat, fat, and fiber intake to the risk of colon cancer in a prospective study among women. N Engl J Med 1990; 323: 1664-72.

104. Kato I, Akhmedkhanov A, Koenig K, Toniolo PG, Shore RE, Riboli E. Prospective study of diet and female colorectal cancer: the New York University Women's Health Study. Nutr Cancer 1997; 28: 276-81.

105. Giovannucci E, Rimm EB, Stampfer MJ, Colditz GA, Ascherio A, Willett WC. Intake of fat, meat and fiber in relation to risk of colon cancer in men. Cancer Res 1994; 54: 2390-7.

106. Ma J, Giovannucci E, Pollak M, Chan JM, Gaziano JM, Willett WC, et al. Milk intake, circulating levels of insulin-like growth factor-I, and risk of colorectal cancer in men. J Natl Cancer Inst 2001; 93: 1330-6.

107. Hirayama T. Epidemiology of prostate cancer with special reference to the role of diet. Natl Cancer Inst Monogr 1979; 53: 149-55.

108. Severson RK, Nomura AMY, Grove JS, Stemmermann GN. A prospective study of demographics, diet, and prostate cancer among men of Japanese ancestry in Hawaii. Cancer Res 1989; 49: 1857-60.

109. Hsing AW, McLaughlin JK, Schuman LM, Bjelke E, Gridley G, Wacholder S, et al. Diet, tobacco use and fatal prostate cancer: Results from the Lutheran Brotherhood cohort study. Cancer Res 1990; 50: 6836-40.

110. Le Marchand L, Kolonel LN, Wilkens LR, Myers BC, Hirohata T. Animal fat consumption and prostate cancer: a prospective study in Hawaii. Epidemiology 1994; 5: 276-82.

111. Veierød MB, Laake P, Thelle DS. Dietary fat intake and risk of prostate cancer: a prospective study of 25,708 Norwegian men. Int J Cancer 1997; 73: 634-8.

112. Schuurman AG, van den Brandt PA, Dorant E, Goldbohm RA. Animal products, calcium and protein and prostate cancer risk in the Netherlands Cohort Study. Br J Cancer 1999; 80: 1107-13.

113. Terry P, Lichtenstein P, Feychting M, Ahlbom A, Wolk A. Fatty fish consumption and risk of prostate cancer. Lancet 2001; 357: 1764-6.

114. Augustsson KM, Michaud DS, Rimm EB, Leitzmann MF, Stampfer MJ, Willett WC, et al. A prospective study of intake of fish and marine fatty acids and prostate cancer. Cancer Epidemiol Biomark Prev 2003; 12: $64-7$.

115. Mills PK, Beeson L, Phillips RL, Fraser GE. Cohort study of diet, lifestyle and prostate cancer in Adventist men. Cancer 1989; 64: 598-604.

116. Statens råd for ernæring og fysisk aktivitet, Statens næringsmiddeltilsyn, Institutt for ernæringsforskning: Den store matvaretabellen. Oslo: Gyldendal Norsk Forlag; 2001.

117. Platz EA, Giovannucci E. Vitamin D and calcium in colorectal and prostate cancers. In: Heber D, Blackburn GL, Go VLW, eds. Nutritional oncology. San Diego, CA: Academic Press; 1999. p. 223-52. 
118. Aronson W, Yip I, Dekernion J. Prostate cancer. In: Heber D, Blackburn GL, Go VLW, eds. Nutritional oncology. San Diego, CA: Academic Press; 1999. p. 453-61.

119. Landsforeningen for kosthold og helse. Fettsyreinnhold i matvarer. Oslo, 1988. (In Norwegian.)

120. Statens livsmedelsverk. Livsmedelstabell aminosyror. Statens livsmedelsverk, 1996.

121. Combs G Jr, Clark LC. Selenium and cancer. In: Heber D, Blackburn GL, Go VLW, eds. Nutritional oncology. San Diego, CA: Academic Press; 1999. p. 215-22.

122. Potter JD, Slattery ML, Bostick RM, Gapstur SM. Colon cancer: a review of epidemiology. Epidemiol Rev 1993; 15: 499-545.

123. Willett W. Nutritional epidemiology. New York: Oxford University Press; 1998.

124. Armstrong B, Doll R. Environmental factors and cancer incidence and mortality in different countries, with special reference to dietary practices. Int $\mathbf{J}$ Cancer 1975; 15: 617-31.

125. Rohan TE, Bain CJ. Diet in the etiology of breast cancer. Epidemiol Rev 1987; 9: 120-44.

126. Willett WC, MacMahon B. Diet and cancer: an overview (part I \& II). N Engl J Med 1984;319:633-8, 697703.

127. Schatzkin A, Greenwald P, Byar DP, Clifford CK. The dietary fat-breast cancer hypothesis is alive. JAMA 1989; 261: 3284-7.

128. Prentice RL, Sheppard L. Dietary fat and cancer: consistency of the epidemiologic data, and disease prevention that may follow from a practical reduction in fat consumption. Cancer Causes Control 1990; 1 : 81-97.

129. Byers T. Nutritional risk factors for breast cancer. Cancer 1994; 74: 288-95.

130. Riboli E, Hunt KJ, Slimani N, Ferrari P, Norat T, Fahey M, et al. European Prospective Investigation into Cancer and Nutrition (EPIC): study populations and data collection. Public Health Nutr 2003; 5(6B): $1113-24$.

131. Welch AA, Lund E, Amiano P, Dorronsoro M, Brustad M, Kumle M, et al. Variability of fish consumption within the 10 European countries participating in the European Investigation into Cancer and Nutrition (EPIC) study. Public Health Nutr 2003; 5(6B): $1273-85$.

132. Hjartåker A, Engeset D, Brustad M, Lund E. Fiskekonsum og kreftrisiko blant norske kvinner - The Norwegian Women and Cancer Study (NOWAC). Nor Epidemiol 2000; 1: 63-70.

133. Hjartåker A, Lund E, Bjerve KS. Serum phospholipid fatty acid composition and habitual intake of marine foods registered by a semi-quantitative food frequency questionnaire. Eur J Clin Nutr 1997; 51: 736-42.

\section{Anette Hjartåker}

Institute for Basic Medical Sciences, Section of Medical Statistics, University of Oslo, PO Box I 122 Blindern, N-03 17, Oslo, Norway Tel: +4722 851047

Fax: +47 22851313

E-mail: anette.hjartaker@basalmed.uio.no 